\title{
CINCO LIBROS SOBRE LOS ÁRABES DEL MEDITERRÁNEO Y EL ÁFRICA SUBSAHARIANA: CUOQ, FALL, DRAHMANI-ISSIFOU, SAAD, VILLAR RASO
}

Por MIKELL DE EPALZA

No es coincidencia que hayan salido en estos últimos años varios libros importantes, entre otros, sobre la historia común que une, a pesar de las distancias, los árabes del Mediterráneo con el África subsahariana. No en vano los historiadores árabes medievales consideraban al Mágreb (actuales Marruecos, Argelia, Túnez y Libial como una isla, entre dos mares, el Mediterráneo líquido y el Sáhara sólido, que les unían más que separaban de las tierras de Al-Andalus y del África Negra o Bilād As-Südān.

Estos libros, científicos o divulgativos, son el resultado de la descolonización de los territorios africanos y del acceso de esos países a la madurez política y científica moderna. Por eso no hay que extrañarse de que su historia interese cada vez más y que historiadores nacionales y extranjeros investiguen aspectos nuevos de su pasado. Entre esos temas históricos, las relaciones con los árabes-musulmanes del Mediterráneo, de donde vino la civilización musulmana al África subsahariana, tiene una prioridad absoluta, a pesar de las dificultades lingüísticas, ya que esos países musulmanes no tienen al árabe como lengua nacional o de cultura, sino el francés o el inglés, además de sus lenguas locales, generalmente ágrafas.

El primero de los libros que queremos presentar responde a una necesidad fundamental: poner al alcance de los africanos e investigadores que no conocen el árabe los textos árabes fundamentales para la historia africana, en el período que en Europa se llama medieval. Es el libro del investigador y eclesiástico francés Joseph M. Cuoq, Receuil des sources arabes concernant l'Afrique Occidentale du VIII' au XV/e siècle (Bilād as-Südān), París, Editions du C. N. R. S., 1975. De una manera perfectamente sistemática, presenta y traduce los textos y autores que mencionan las tierras subsaharianas. La selección es prácticamente exhaustiva (nuevas ediciones to completarán, evidentemente). Los escuetos comentarios y aclaraciones iluminan mucho unos textos de difícil acceso. Es un libro básico. En él figuran varios au tores $y$ noticias de origen andalusí (Abū Hāmid de Granada, Al-Bakrĩ, etcétera). 
Complementario del anterior, con las fuentes cartográficas, es el libro del profesor de la Universidad de Dakar (Senegal), Yoro K. Fall, L 'Afrique à la naissance de la cartographie moderne (14\%/15० siècle: les cartes majorquines). París, Karthala-C. R. A., 1982. Es un estudio muy profundo sobre la cartografía mallorquina y su visión del África subsahariana. Superando el mero positivismo científico descriptivo, analiza con inteligencia y profundidad los presupuestos ideológicos y políticos de los que fabricaron esos mapas o portulanos. Por eso este libro es de obligada lectura y reflexión no sólo para los que estudian la historia del Bilād as-Südān o de las islas Baleares o islas de Shara Al-Andalus (a/yuzur aš-sarqiyya), sino para todos los historiadores del Mediterráneo y de su representación cartográfica.

El libro de Zakari Dramani-Issifou, profesor e investigador en las universidades de París y Cotonou (Benin), es una investigación histórica muy elaborada: $L$ 'Afrique Noire dans les relations internationales au XV/e siècle. Analyse de la crise entre le Maroc et le Sonrhai, Paris, Carthala-C. R. A., 1982. Analiza las relaciones políticas de los estados subsaharianos (sí, había estados subsaharianos y tenían complejas relaciones diplomáticas) en relación con la política mediterránea, especialmente con Marruecos y el Imperio Otomano. Muchos acontecimientos de la política musulmana en el siglo XVI llos musulmanes poseían las tres cuartas partes de las costas del Mediterráneo, de los Baicanes al Mágrebl dependen de acontecimientos del otro lado del Sáhara. Este libro da unas dimensiones y unos horizontes insospechados a la historia hispano-musulmana del XVI, por ejemplo a la famosa expedición marroqui de hispanos (moriscos y convertidos al Islam) a Timbuktu (1590-1591), clave de la crisis entre Marruecos y el imperio Sonrhai.

Precisamente esta expedición, que ha tenido una ingente bibliografía también en castellano, ha sido recientemente el tema de una novela con título patriotero: Manuel Villar Raso, Las Españas perdidas lodisea africana de Yuder Pachá $y$ de los moriscos granadinos). Granada, Editoriales Andaluzas Reunidas, 1984. Esta creación literaria, basada en la historia, expresa también un cierto entusiasmo popular, reflejado en la expedición granadina de 1984, a la búsqueda de los descendientes de esos moriscos emigrados. A pesar de manifestaciones sensacionalistas en la prensa, los restos que hayan podido encontrar no pueden pasar de las amables afirmaciones de un común origen andalusi (y no andaluz), hechas evidentemente en francés y no en viejo castellano. Pero es signo muy evidente, también, de un común deseo de recuperación de un pasado árabe y mediterráneo, que alcanza las otras orillas del otro mar del Mágreb, el de arenas del Sáhara.

Finalmente, el máximo nivel de relaciones entre los puertos islámicos de estos dos mares lo puede significar el libro de Elías N. Saad, investigador árabe originario de Oriente Medio y profesor en los Estados Unidos (Wellesley College, Massachusetts). Social history of Timbuktu: the role of Muslim scholars and notables. 1400-1900, Cambridge, Cambridge University Press, 1983. Analiza la sociedad islámica de esa ciudad del actual Mali, a partir de sus élites sociales, que son las más documentadas por las fuentes, en la época pre-colonial estudiada. El análisis sociológico de las fuerzas en presencia es interesantísimo, porque refleja a nivel local una dinámica que se da en todas las sociedades islámicas. Con los diferentes condicionamientos de espacio y tiempo, sirve para comprender también la actuación de los "notables" en la sociedad urbana andalusí. 
MEDITERRÁNEO Y EL ÁFRICA SUBSAHARIANA... | Epalza

Estos cinco libros, cada uno en su campo, muestran el interés que supone para los estudios árabes la corriente de investigación sobre la historia del África subsahariana. 